\title{
Friendly Takeover, or: the Power of the 'First Word'. The German Constitutional Court Embraces the Charter of Fundamental Rights as a Standard of Domestic Judicial Review
}

\author{
Daniel Thym*
}

Five decades of interaction between the Bundesverfassungsgericht and the Court of Justice - Reversal of the Solange decisions - Jurisdictional upgrade of the Charter under domestic constitutional law - Continuity of the ultra vires and constitutional identity caveats - Differences between the First and Second Senate in the approach towards EU law - Preliminary references as a new normality - Projection of the experience and doctrinal rigour of the German fundamental rights case law on the European level - 'Primary' application of the Grundgesetz as pragmatic guidance Gradual evolution of overarching standards - Ordinary courts as an institutional counterbalance to the Bundesverfassungsgericht - Insistence on leeway for relative national autonomy in the interpretation and application of the Charter.

\section{INTRODUCTION: THE 'LONGUE DURÉE' FROM CONFLICT TO TEAMWORK}

Relations between national constitutional courts and the European Court of Justice are an evergreen of European constitutional law. One of the best-known protagonists is the German Bundesverfassungsgericht, which has played a central role in debates about the constitutional limits of EU integration from the 1970 s onwards. Our attention is drawn, therefore, when the First Senate of the Constitutional Court engaged in a significant reversal of its fundamental rights case law which revisited - and altered - core assumptions of domestic constitutional law which had defined its approach to EU law ever since the famous Solange rulings. Two decisions

*Professor Dr Daniel Thym, LLM (London) is a Professor of Public, European and International Law at the University of Konstanz, Germany.

European Constitutional Law Review, 16: 187-212, 2020

(C) The Authors 2020. This is an Open Access article, distributed under the terms of the Creative Commons Attribution licence (http://creativecommons.org/licenses/by/4.0/), which permits unrestricted re-use, distribution, and reproduction in any medium, provided the original work is properly cited. doi: $10.1017 /$ S1574019620000127 
of November 2019 on the 'right to be forgotten' mark a tectonic shift that will profoundly transform German constitutional law and scholarship and will reinforce the shift towards a composite framework of axiomatic 'unity in diversity' in the panEuropean human rights jurisprudence on the basis of the Charter of Fundamental Rights, the European Convention and national constitutions. This change of direction of the First Senate is even more remarkable, since it contrasts markedly with the ultra vires verdict of the Second Senate five months later. We are witnessing with a Janus-faced approach towards EU affairs among the two senates of the German Constitutional Court.

Epic stories invite the observer to step back and to observe broader trends at an intermediate level of abstraction. In this respect, the Right to be Forgotten decisions can offer useful insights, precisely because they reconsider a position of principle which had prompted the Court of Justice to embrace human rights standards in the early 1970s. Extending deep into the past, the close and often conflictual relationship between judges in Luxembourg and Karlsruhe allows us to combine the analysis of current events with an awareness of long-term transformation - in line with the historical concept of the 'longue durée', accentuating slowly-changing structures that our usual focus on contemporary events tends to neglect. ${ }^{1}$ This perspective is essential to the argument in this paper, that the decisions on the 'right to be forgotten' reflect and reinforce a fundamental realignment of European constitutional law. While the Bundesverfassungsgericht is comparatively late in changing course, its institutional weight may have a lasting impact on the direction of fundamental rights law.

Martial metaphors were - and continue to be - widely used to describe relations between the Bundesverfassungsgericht and the Court of Justice. This was adequate for a situation in which the German Constitutional Court strictly delineated domestic and supranational fundamental rights standards and erected stern hurdles to EU integration under the ultra vires and constitutional identity benchmark, which the Second Senate reconfirmed in its PSPP judgment. Notwithstanding this conflict, the ground-breaking Right to be Forgotten decisions established a new paradigm in the field of fundamental rights that economic allegories can grasp better than martial language, since they overcome zero-sum games, in which one party gains what the other loses. We may compare the judicial about-turn of the First Senate with a merger of two companies, who had been competing for market share for decades. The new joint venture adopts the brand name of the company that is better known internationally, while internal quarrels continue about who fills the top jobs and defines the corporate culture. These disputes are no longer about an either-or dichotomy, since both sides stand to win or lose jointly from the decisions taken. The new situation should not be misconstrued,

\footnotetext{
${ }^{1}$ See F. Braudel, 'La longue durée', 13 Annales: Économies, Sociétés, Civilisations (1958) p. 725-753.
} 
therefore, as a surrender or defeat of the Constitutional Court; it resembles a merger, which might even turn out to be a 'friendly takeover' when the German judges project the weight of decades of elaborate human rights case law onto the European level.

This contribution will chart in four steps the implications of this novel judicial stance for the pan-European debate. An inspection of the longue durée of relations between judges in Karlsruhe and Luxembourg shows that the interpretative metamorphosis reflects changing contours of the legal fundamental rights landscape to which other constitutional courts across Europe were much quicker to adapt. On the basis of the Charter, the Court of Justice expanded its case law into core domains of constitutional adjudication, thereby creating an original overlap of domestic and supranational human rights standards, which rendered ineffective the Bundesverfassungsgericht's previous 'separatist' agenda. Like most other judgments, the Right to be Forgotten decisions are defined by substantive and procedural idiosyncrasies of German constitutional law, which might have the sideeffect of upgrading the legal effects of the Charter from primacy to supremacy by means of domestic constitutional fiat. At the same time, the new openness towards EU law should not be misinterpreted as a surrender of the ultra vires and constitutional identity caveats, which are alive and kicking in the judicial practice of the Bundesverfassungsgericht's Second Senate.

Our third section will explore how future relations between the Bundesverfassungsgericht and the Court of Justice might unfold. On the basis of a profound and mature understanding of EU law and practice, the Right to be Forgotten rulings embrace preliminary references as a channel of communication, which should not be misread as an act of subordination. Judges in Karlsruhe will project the wealth of experience and the doctrinal rigidity of the German human rights tradition, thus pressing the Court of Justice to develop a coherent and elaborate set of standards. Judges in Luxembourg may find out that the 'first word' of preliminary references can exert more influence than the latent threat of the 'last word' of the constitutional caveats. Notwithstanding the novel and earnest commitment to the Charter, the decisions contain elements which could potentially signal continued human rights introspection. It will be argued, however, that the reasoning and predominant tenor of the decisions do not support such a reading, which, moreover, would be complicated by the loyal cooperation between other domestic courts and the Court of Justice. The decisions may herald, rather, the re-entry of a powerful court into the transnational debate on how to build an effective multi-level network of human rights protection.

\section{Background AND Contents: the Charter's COMing home}

It is well known that the Court of Justice started developing fundamental rights as unwritten general principles in the 1970s. What is less often remembered, 
however, is that this was an attempt to fend off challenges to the primacy of Union law by the Bundesverfassungsgericht. ${ }^{2}$ In its Solange I ruling, following the Court's judgment in Internationale Handelsgesellschaft, the Constitutional Court had insisted that the German Constitution would prevail as long as (solange) the process of European integration has not led to a legally binding catalogue of fundamental rights which ... offers a level of protection resembling, though not necessarily duplicating, the fundamental rights in the Grundgesetz: ${ }^{3}$ Although judges later accepted the European Court of Justice's methodology and case law as functionally equivalent ${ }^{4}$ the Charter might have appeared as an ultimate victory. The EU obtained the binding catalogue upon which the Court had originally insisted. It is telling that the Charter was initiated by the German Council Presidency and drafted by a Convention that was presided over by a former German chief justice. ${ }^{5}$ It was thanks to the broader context that it took the Bundesverfassungsgericht 20 years to embrace its constitutional stepchild wholeheartedly.

\section{Preference for domestic fora: powers, protection and patriotism}

Three overlapping trends can explain the previous reluctance of the German Constitutional Court to actively engage in the pan-European human rights discourse. First, it has been widely documented that judges in Karlsruhe have kept a watchful eye on the Court of Justice in recent decades because of its interpretative dynamism and the lack of vigour in constraining the powers of the European Union. The Bundesverfassungsgericht has achieved worldwide recognition and critique for its constitutional control standards of ultra vires and constitutional identity review, which erected counterbalances to real or perceived power-grabs by the EU institutions, including by the European Court of Justice itself. ${ }^{6}$ To be sure, these areas of conflict did not - with the exception of human dignity in the context of the European Arrest Warrant - directly concern fundamental rights. ${ }^{7}$ Nevertheless, maintaining a critical distance from the Charter reflected

${ }^{2}$ See the historic study by B. Davies, 'Internationale Handelsgesellschaft and the Miscalculation at the Inception of the ECJ's Human Rights Jurisprudence', in F. Nicola and B. Davies (eds.), EU Law Stories (Cambridge University Press 2017) p. 157-177; and G. de Búrca, 'The Evolution of EU Human Rights Law', in P. Craig and G. de Búrca (eds.), The Evolution of EU Law, 2nd edn. (Oxford University Press 2011) p. 465 at p. 477-479.

${ }^{3}$ BVerfG 29 May 1974, 2 BvR 197/83, Solange I, p. 285.

${ }^{4}$ See BVerfG 22 October 1986, 2 BvR 197/83, Solange II.

${ }^{5}$ Cf Annex IV to the Cologne European Council, Presidency Conclusions of 4 June 1999.

${ }^{6}$ For an up-to-date overview, see F.C. Mayer, 'The Case of Germany', in C. Landfried (ed.), Judicial Power (Cambridge University Press 2019) p. 183 at p. 190-201; for the comparative setting see M. Wendel, Permeabilität im europäischen Verfassungsrecht (Mohr Siebeck 2012) chs. 10-11.

${ }^{7}$ See A. Bobić, 'Developments in the EU-German Judicial Love Story', 21 GLJ (2020) Special Issue $S 1$ p. 31 at p. 34-37. 
a broader unease with the scope and direction of the European project as a whole, and the role of the judges in Luxembourg.

Second, there was a genuine concern with the case law of the Court of Justice. Rereading the supranational judgments on fundamental rights, one is bound to notice a shift from the late 2000s onwards when the Charter buttressed a fresh determination on the part of the Court in Luxembourg to engage in earnest with human rights in contrast to the comparatively superficial examinations that had previously occurred. ${ }^{8}$ Data protection is a case in point. Prominent rulings considerably reinforced the level of protection when the Court of Justice banned the outright publication of the names of the recipients of agricultural subsidies, ${ }^{9}$ reined in data retention, ${ }^{10}$ annulled a safe harbour agreement with the US, ${ }^{11}$ and established a strong 'right to be forgotten' ${ }^{12}$ five years before the decisions of the Bundesverfassungsgericht. When it came to data protection, judges in Luxembourg overtook their domestic peers as champions of robust safeguards in the digital age. That was worrisome for the German Constitutional Court, which took pride in its historic leading role in the formation of a human right to data protection. ${ }^{13}$

Third, the Bundesverfassungsgericht is much more than an ordinary court, in the same way that constitutional norms are not simple statutory prescriptions. They convey a set of normative values and express basic choices of societies, which change over time. ${ }^{14}$ International observers should recognise that the legendary judgments on EU integration represent only an offspring of the domestic significance of the Constitutional Court, which rests essentially on its human rights case law. Arguably, judges have successfully managed to portray the Grundgesetz as a microcosm of social and political conflicts. ${ }^{15}$ The very

${ }^{8}$ See S.I. Sánchez, 'The Court and the Charter', 49 CML Rev (2012) p. 1565 at p. 1576-1604; and the classic critique by J.H.H. Weiler and N. Lockhart, "'Taking Rights Seriously" Seriously', 32 CML Rev (1995) p. 51 at p. 67-92.

${ }^{9}$ Cf ECJ 9 November 2010, Cases C-92/09 \& 93/09, Volker \& Markus Schecke.

${ }^{10} \mathrm{Cf}$ ECJ 8 April 2014, Cases C-293/12 \& C-594/12, Digital Rights Ireland.

${ }^{11} C f$ ECJ 6 October 2015, Case C-362/14, Schrems.

${ }^{12}$ Cf ECJ 13 May 2014, Case C-131/12, Google Spain \& Google paras. 68-88.

${ }^{13}$ See M. Goldmann, 'As Darkness Deepens', 21 GLJ (2020) Special Issue S1 p. 45 at p. 46-48; and F. Wollenschläger, 'Föderalisierung des EU-Grundrechtsschutzes', Europäische Zeitschrift für Wirtschaftsrecht (2020) p. 121 at p. 121.

${ }^{14}$ See R.R. Cover, 'Nomos and Narrative', 97 Harvard Law Review (1983) p. 4-46; and U. Volkmann, Grundzüge einer Verfassungslehre (Mohr Siebeck 2013).

${ }^{15}$ See C. Schönberger, 'Anmerkungen zu Karlsruhe', in C. Möllers et al., Das entgrenzte Gericht (Suhrkamp 2011) p. 9 at p. 59-65; and D. Grimm, 'Integration by Constitution', 3 ICON (2005) p. 193 at p. $198-203$. 
German concept of 'Verfassungspatriotismus' (constitutional patriotism) ${ }^{16}$ aptly grasps this broader function of constitutional adjudication for political processes and identificatory patterns. What may sound theoretical to international observers, arguably constitutes an important contextual factor motivating the Right to be Forgotten decisions. By embracing the Charter, judges in Karlsruhe open up a new terrain for the projection and resolution of social and political conflicts, which it would otherwise have had to abandon under the older 'separatist' case law. We shall see later that the concern about democratic self-determination by means of constitutional adjudication resurfaces in the new rulings.

\section{From human rights' separatism to fusion}

Sometimes it is a disadvantage to have a long relationship. Patterns developed early on can endure over decades, irrespective of changes in the broader environment. A telling example is the case law of the German Constitutional Court on fundamental rights, whose foundations I described as the 'separation thesis' on an earlier occasion. ${ }^{17}$ It essentially aimed at a strict demarcation of spheres of influence on the basis of the foundational choice in the seminal Solange decisions in which the Bundesverfassungsgericht recognised the primacy of EU law and withdrew from the application of domestic standards. It was a sign of deference to Luxembourg when it declared constitutional complaints by individuals and references by lower courts to be 'inadmissible a priori' ${ }^{18}$ if they challenged Union law on the basis of the fundamental rights in the Grundgesetz. In recent years, this approach has been fine-tuned and extended to areas such as the transposition of directives, where national and European law are intrinsically linked. ${ }^{19}$ In doing so, judges in Karlsruhe reconfirmed the 'separation thesis'; they stepped back and let colleagues in Luxembourg take the helm.

It is important to understand that the separation of respective spheres of influence followed a pro-European impetus, which the Court of Justice actively supported in its early fundamental rights case law, whose central objective had been to buttress the primacy of Union law vis-à-vis national constitutional review. The judicial assertion of distinct and separate standards at national and European level was, at the time, no German hobby horse. On the contrary, judges in

\footnotetext{
${ }^{16} \mathrm{On}$ its evolution and current status, see D. Thym, 'Verfassungspatriotismus in der Einwanderungsgesellschaft', 145 Archiv des Öffentlichen Rechts (2020), forthcoming; and H. Vorländer, 'Integration durch Verfassung?', in H. Vorländer (ed.), Integration durch Verfassung (Springer 2002) p. 9-40.

${ }^{17}$ See D. Thym, 'Separation versus Fusion', 9 EuConst (2013) p. 391 at p. 401-407.

${ }^{18} \mathrm{BVerfG} 7$ June 2000, 2 BvL 1/97, Bananenmarktordnung reconfirming the Solange II ruling.

${ }^{19}$ See Thym, supra n. 17, p. 404-405; and M. Wendel, 'Neue Akzente im europäischen Grundrechtsverbund', Europäische Zeitschrift für Wirtschaftsrecht (2012) p. 213 at p. 215-217.
} 
Luxembourg eagerly drew a clear line between the EU legal order and national constitutions notwithstanding the abstract assertion of the supranational standards being based on the constitutional traditions common to the member states. With the emphasis on the autonomy and primacy of Union law vis-à-vis national fundamental rights, the Court of Justice followed its own variant of the 'separation thesis'. ${ }^{20}$

While the German Constitutional Court kept on pursuing the separatist agenda, it was the Court of Justice which changed course. It is well known that the novel vigour of the human rights case law combined a lenient approach to the scope of the Charter in Akerberg Fransson and follow-up cases with a parallel application of domestic constitutional standards as long as they did not compromise the primacy of Union law - a standpoint that can described as the fusion thesis'. ${ }^{21}$ For our purposes, it should be emphasised that the Court of Justice accepted that member states should have breathing space for country-specific solution, provided that the secondary law does not prescribe a uniform position. ${ }^{22}$ Yet, this relative autonomy was not brought about by demarcating spheres of influence. National deviations are blended into the application of the Charter and are combined with a broad definition of its field of application. ${ }^{23}$ It is this shift of emphasis from separation to fusion on the side of the Court of Justice that the judges in Karlsruhe struggled to cope with.

Data protection is a good example to illustrate the Catch-22 situation with which the Bundesverfassungsgericht was confronted. On the basis of the separation thesis, it had to accept that a crown jewel of its domestic case law was gradually being taken over by the Court of Justice in cooperation with ordinary domestic courts. Judges in Karlsruhe could protest against the wide definition of the scope of the Charter, as it did to little avail in the Counter-Terrorism Database judgment, when it sent a latent ultra vires and constitutional identity

\footnotetext{
${ }^{20}$ See Thym, supra n. 17, p. 407-408; and P. Allott, 'Preliminary Rulings - another infant disease?', 25 EL Rev (2000) p. 538 at p. 541-543.

${ }^{21}$ Thym, supra n. 17, p. 401-404; A. von Bogdandy, 'Constitutional Principles', in A. von Bogdandy and J. Bast (eds.), Principles of European Constitutional Law, 1st edn. (Hart Publishing 2006) p. 3 at p. 34-50 argued that it is a regular feature of federal systems to concentrate on unitybuilding principles early on, when the federation is still fragile and usually has few competences, while the central institutions can be expected to shift towards the recognition of diversity when the federal edifice becomes more solid.

${ }^{22}$ For a paradigmatic statement see ECJ 26 February 2013, Case C-617/10, Åkerberg Fransson, para. 29.

${ }^{23}$ Similarly D. Sarmiento, 'Who's Afraid of the Charter?', 50 CML Rev (2013) p. 1267 at p. 1291-1303; A. Torres Pérez, 'The Federalizing Force of the EU Charter of Fundamental Rights', 15 ICON (2017) p. 1080 at p. 1093-1095; and G. Martinico and G. Repetto, 'Fundamental Rights and Constitutional Duels in Europe', 15 EuConst (2019) p. 731 at p. $748-751$.
} 
threat to Luxembourg, ${ }^{24}$ which, however, would have been difficult to realise in light of the wording of the Treaties and the novel vigour of the supranational case law. ${ }^{25}$ They had generously limited their scrutiny of domestic data retention rules to areas of implementing discretion, without questioning the validity of the corresponding directive, in a seemingly pro-European stance ${ }^{26}$ - only to find out a few years later that Luxembourg struck down the Directive ${ }^{27}$ and established a generous 'right to be forgotten' in another judgment, ${ }^{28}$ thereby dethroning Karlsruhe as the champion of data protection at a time when the first German Right to be Forgotten case was already pending. The adoption of the General Data Protection Regulation finally seemed to render the Bundesverfassungsgericht irrelevant. ${ }^{29}$ If it stuck with the separation thesis, the conclusion in many cases would have been: 'manifestly inadmissible - ask Luxembourg'.

\section{Right to be Forgotten I \& II}

On 6 November 2019, the First Senate of the Bundesverfassungsgericht pulled the emergency brake and engaged in a powerful about-turn when it joined other constitutional courts across Europe in subscribing to the 'fusion thesis'. It has been mentioned above that this transformation had been in the making for years, during which judges had pondered their options, manifesting themselves in the defensive Counter-Terrorism Database judgment and the extra-judicial writing of members of the bench. ${ }^{30}$ The end result is the opposite of a spontaneous eruption: the argument stretches over more than 50 densely-written pages. The general principles alone cover roughly 10,000 words and are a prime example of a mature combination of doctrinal arguments and conceptual ideas, which reveal an intimate knowledge and understanding of EU constitutional law.

The facts underlying both cases were comparatively straightforward. They concerned constitutional complaints, to start with by the chairperson of a small

\footnotetext{
${ }^{24}$ See BVerfG 24 April 2013, 1 BvR 1215/07, Antiterrordatei, paras. 88-90; and Thym, supra n. 17 , p. $396-397$.

${ }^{25}$ There are legitimate reasons why Art. 6 TEU and Art. 51(1) of the Charter support the ECJ's case law as a matter of principle, which similarly could no longer be accused of not protecting citizens' rights strongly enough, thereby infringing constitutional identity.

${ }^{26}$ BVerfG 11 March 2008, 1 BvR 256/08, Vorratsdatenspeicherung, paras. 134-135.

${ }^{27}$ Cf ECJ, supra n. 10.

${ }^{28}$ See ECJ, supra n. 22.

${ }^{29}$ As the reporting judge of the recent rulings warned in an open editorial: see J. Masing, 'Ein Abschied von den Grundrechten', Süddeutsche Zeitung, 9 January 2012, p. 10.

${ }^{30}$ See J. Masing, 'Unity and Diversity of European Fundamental Rights Protection', 41 EL Rev (2016) p. 490-512; and G. Britz, 'Grundrechtsschutz durch das Bundesverfassungsgericht und den Europäischen Gerichtshof’, Europäische Grundrechte-Zeitschrift (2015) p. 275-281.
} 
company which had been the object of a critical TV documentary in 2010, which could still be found online and ranked prominently among online search results for the individual name of the chairperson. The plaintiff had failed in lower courts to oblige Google to delete or relegate the reference to the documentary (Right to be Forgotten II). Similarly, a private person sought a modification of search results to prevent the general public from permanently associating his name with a double homicide on a sailing boat in the early 1980s, which had been reported in the Spiegel magazine and was available in its online archive (Right to be Forgotten I). While the facts were similar, the legal context differed, since the latter case was covered by the 'media privilege' under Article 85(2) of the General Data Protection Regulation, which, according to the Court's previous interpretation, authorises member states to lay down exceptions for journalistic purposes. In this scenario, domestic constitutional rules can be applied in parallel to the Charter, while the former situation is governed exclusively by supranational standards as a result of full harmonisation.

Judges used this distinction to develop a graded approach. The most remarkable change of direction concerns scenarios of full harmonisation in the Right to be Forgotten II decision: instead of declaring constitutional complaints inadmissible, as the Constitutional Court had done ever since the Solange II ruling more than 30 years ago, it reasserted its jurisdiction in full compliance with and under explicit recognition of the primacy of Union law over the Grundgesetz (with the exception of the ultra vires and constitutional identity caveats). ${ }^{31}$ Following the example of the Austrian, Belgian, French and Italian constitutional courts, the First Senate extended its jurisdiction to the Charter, ${ }^{32}$ which it promised to apply in loyal cooperation with the Court of Justice, whom it designated as the 'ultimate interpreter' and which it promised to consult regularly through preliminary references, including on when a situation of full harmonisation arises. ${ }^{33}$

By contrast, the Right to be Forgotten I ruling recognised the parallel application of the Charter and the Grundgesetz in scenarios of member state discretion, including an affirmative reference to the primacy of Union law in cases of conflict under the controversial Melloni judgment. ${ }^{34}$ In line with the 'fusion thesis' described earlier, the First Senate highlighted the crucial importance of room for country-specific solutions in areas in which secondary legislation does not

${ }^{31}$ See BVerfG 6 November 2019, 1 BvR 276/17, Recht auf Vergessen II, paras. 42-45; for an English summary, see Press Release No. 84 of 27 November 2019, 〈www.bundesverfassungsgericht. de/EN/Presse/presse_node.html $\rangle$, visited 18 June 2020.

${ }^{32}$ See BVerfG, supra n. 31, paras. 50-67.

${ }^{33}$ See BVerfG, supra n. 31, paras. 68-82.

${ }^{34}$ See BVerfG 6 November 2019, 1 BvR 276/17, Recht auf Vergessen II, paras. 40-48; for an English summary, see the Press Release No. 83, supra n. 31. 
prescribe a uniform standard. It noted corresponding safeguards in primary law and acknowledged the recent practice of the Court in Luxembourg in this regard. ${ }^{35}$ In a somewhat ambiguous move, which will be discussed below, the First Senate established a 'presumption' that the Grundgesetz generally guarantees the same level of protection and should be applied 'primarily' by the Constitutional Court and other domestic courts, ${ }^{36}$ even though that presumption did not imply an irrelevance of the Charter, which might influence the interpretation of the Constitution, thereby promoting 'overarching connectivity' of the Charter, national constitutions and the European Convention on Human Rights as 'the foundation of human rights protection that is open to diversity and rests on a common ground'. ${ }^{37}$

\section{GERMAN CONSTITUTIONAL LAW: SPECIFIC PATTERNS}

In its reasoning, the Bundesverfassungsgericht explicitly recognised that the domestic application of the Charter followed the example set by the constitutional courts of Austria, Belgium, France and Italy, although the solution promulgated by the German Court differs in various respects from the position of the sister courts. ${ }^{38}$ Notwithstanding the particularities of each ruling, which partly reflect the distinct domestic context, ${ }^{39}$ the reference symbolically emphasises that the German Constitutional Court accepts its role as one - albeit self-conscious - actor among many, which cannot necessarily project the German approach as a model anyone should follow. ${ }^{40}$ When it comes to the specifics of the German constitutional framework, three themes deserve our attention.

\section{Jurisdiction beyond the original intent}

Judges in Karlsruhe famously blame the Court of Justice for being negligent with the principle of attributed powers - a criticism that had always contrasted with the interpretative flexibility of the Bundesverfassungsgericht's case law on European affairs,

\footnotetext{
${ }^{35}$ See BVerfG, supra n. 34, paras. 49-54; similarly beforehand D. Thym, 'Vereinigt die Grundrechte!', Juristenzeitung (2015) p. 53 at p. 58-60.

${ }^{36}$ See BVerfG, supra n. 34, paras. 55-72.

${ }^{37} \mathrm{BVerfG}$, supra n. 34, paras. 58 and 59 (own translation).

${ }^{38} \mathrm{BVerfG}$, supra n. 34, para. 50 noted the parallelism in the abstract and did not discuss differences; for a comparative analysis see $\mathrm{M}$. Wendel, 'Das Bundesverfassungsgericht als Garant der Unionsgrundrechte', Juristenzeitung (2020) p. 157 at p. 163-164.

${ }^{39}$ See F. Fabbrini, Fundamental Rights in Europe (Oxford University Press 2014) p. 255-258.

${ }^{40}$ As remarked by BVerfG, supra n. 34, para. 71 .
} 
including its conspicuously lenient treatment of the constitutional admissibility yardsticks. ${ }^{41}$ The Court's Second Senate, which did not decide the Right to be Forgotten cases, has proven particularly innovative in recent years, stretching ever further the options of citizens to verify that EU integration complies with the German Constitution, ${ }^{42}$ even before a recent verdict declared the European Central Bank's Public Sector Purchase Programme to be an ultra vires act. ${ }^{43}$ Against this background, the dynamism of the First Senate's Right to be Forgotten rulings can appear in a different light. They may have diverged from the original intention of the Constitution by extending the Court's jurisdiction to include the Charter of Fundamental Rights, but this result coincides with the broader constitutional effects of Europeanisation.

Initial comments criticised the new rulings for overstretching the wording of Article 94(1)(4a) Grundgesetz, i.e. the constitutional provision on the constitutional complaint procedure, which literally refers to 'basic rights' in the abstract, although it is evident from the context and general scheme of the Constitution that it was not originally intended to cover EU fundamental rights. ${ }^{44}$ The First Senate defended a different position in a reversal of earlier judgments. While the comments on Article 93 remained shallow, ${ }^{45}$ the reasoning elaborated extensively on the constitutional context. It explained at length the constitutional rationale underlying the transfer of sovereign powers to the EU level under today's Article 23 and, in welcome transparency, the objective of ensuring the essential institutional role of the Bundesverfassungsgericht, which EU integration threatened to undermine. ${ }^{46}$ Judges reconfigured, in other words, the constitutional effects of the transfer of sovereign rights, which had always entailed changes to the material constitution that were not reflected in the wording of the Grundgesetz. ${ }^{47}$ The switch from the 'separation' to the 'fusion thesis' builds on a holistic reconstruction

${ }^{41}$ See D. Thym, 'In the Name of Sovereign Statehood', 46 CML Rev (2009) p. 1795 at p. 17961797; it should be noted that the criticism of the ECJ did not embrace its interpretation of the admissibility criteria under TFEU, Art. $263 \mathrm{ff}$.

${ }^{42}$ See the dissenting opinions of Justices D. König, U. Maidowski and C. Langenfeld to BVerfG 13 February 2020, 2 BvR 739/17, Einheitliches Patentgericht; and of Justice G. Lübbe-Wolff, para. 14 to BVerfG 14 January 2014, 2 BvR 2728/13 et al., OMT-Beschluss.

${ }^{43} C f$ BVerfG 5 May 2020, 2 BvR 859/15 et al., EZB-Staatsanleihekaufprogramm.

${ }^{44}$ See M. Breuer, 'Wider das Recht auf Vergessen ... des Bundesverfassungsgerichts!', Verfassungsblog, 2 December 2019, 〈verfassungsblog.de/wider-das-recht-auf-vergessen-des-bundesverfassungsgerichts〉, visited 18 June 2020; and J.A. Kämmerer and M. Kotzur, 'Vollendung des Grundrechtsverbunds oder Heimholung des Grundrechtsschutzes?', Neue Zeitschrift für Verwaltungsrecht (2020) p. 177 at p. 179-180.

${ }^{45}$ See BVerfG, supra n. 31, para. 67.

${ }^{46}$ See BVerfG, supra n. 31, paras. 54-60.

${ }^{47}$ Note that the transfer of competences entails material constitutional amendments, which are not subject to the regular obligation to change the wording in line with Art. 79(1) Grundgesetz; see BVerfG 23 June 1981, 2 BvR 1107/77 et al., Eurocontrol I, p. 36; recently reaffirmed by BVerfG 
of the constitutional material in the same way that the exclusion of jurisdiction under the Solange II decision was similarly not reflected in the wording beyond the mere authorisation to transfer sovereign powers. ${ }^{48}$

From a comparative perspective, it should be noted that the First Senate did not follow the example set by the Austrian Constitutional Court to ground the domestic applicability of the Charter on the EU law principles of effectiveness and equivalence that limit national procedural autonomy, ${ }^{49}$ which had been criticised in the academic literature ${ }^{50}$ and which the First Senate had employed in a previous ruling extending the fundamental rights under the Grundgesetz to legal persons from other member states. ${ }^{51}$ It pursued, rather, the doctrinally secure path of constitutional hermeneutics mirroring the reasoning of the Italian Constitutional Court, which, however, had gone considerably further when it provisionally tried to monopolise the domestic application of the Charter. ${ }^{52}$ The Bundesverfassungsgericht did not go that far. Ordinary courts may continue to send preliminary references to Luxembourg and it remains unclear at this juncture whether they can consult Karlsruhe at all on the validity of domestic law in light of the Charter in situations of full harmonisation. ${ }^{53}$ At present, the Right to be Forgotten decisions concern complaints by individuals only.

\section{From primacy to supremacy by means of constitutional fiat?}

On closer inspection, there is considerable uncertainty about the effects of future judgments applying the Charter domestically. What may seem rather peculiar at first sight is much more than a procedural idiosyncrasy at a symbolic and practical level. It is a defining feature of most centralised systems of constitutional review not only within Germany ${ }^{54}$ - that constitutional courts can declare domestic rules

13 February 2020, supra n. 42, paras. 126-131; and on the discharge from Art. 79 see BVerfG 19 July 2011, 1 BvR 1916/09, Anwendungserweiterung, para. 81.

${ }^{48}$ See Thym, supra n. 35, p. 56-58; and Wendel, supra n. 38, p. 161-162.

${ }^{49} \mathrm{Cf}$ Verfassungsgerichtshof 14 March 2012, U 466/11 and U 1836/11, paras. 26-29.

${ }^{50}$ See M. Pöschl, 'Verfassungsgerichtsbarkeit nach Lissabon', Zeitschrift für Öffentliches Recht (2012) p. 587 at p. 593-595; and F. Merli, 'Umleitung der Rechtsgeschichte', 20 Journal für Rechtspolitik (2012) p. 355 at p. 356-357.

${ }^{51} C f$ BVerfG 19 July 2011, supra n. 47, paras. 75-81.

${ }^{52} \mathrm{C} f$ Corte Costituzionale 7 November 2017, No. 269/2017; and the more lenient later decision of 23 January 2019, No. 20/219; for comments see Martinico and Repetto, supra n. 23, p. 733-739.

${ }^{53}$ However, judges considered (without giving a definite answer) whether ordinary courts may stop being courts of last instance under Art. 267(3) TFEU when it comes to compliance with fundamental rights in line with the comments below.

${ }^{54}$ See M. Bobek, 'The Impact of the European Mandate of Ordinary Courts on the Position of Constitutional Courts', in C. van de Heyning and M. de Visser (eds.), Constitutional Conversations in Europe (Intersentia 2012) p. 287 at p. 288-290. 
null and void if they violate the normatively 'supreme' constitution. By contrast, the 'primacy' of Union law usually requires merely the disapplication of domestic rules, which can remain valid otherwise. ${ }^{55}$ In the German context, such centralised verdicts are the hallmark of the so-called 'concrete constitutional review' procedure, whereby lower courts refer questions of validity to the Constitutional Court, which retains the monopoly to annul parliamentary legislation as being incompatible with the constitution. ${ }^{56}$ This raises the question of how far these procedural particularities extend to the domestic application of the Charter.

In the Right to be Forgotten rulings, the Bundesverfassungsgericht could evade a definite statement on whether the domestic applicability of the Charter implies that it can annul parliamentary legislation which violates a provision of the Charter ${ }^{57}$ and whether the 'concrete constitutional review' procedure applies in the first place. ${ }^{58}$ My prediction is, however, that it will adopt that position in follow-up cases, thereby effectively upgrading the 'primacy' of Union law to 'supreme' constitutional effects, while emphasising that the upgrade occurs of the constitution's free will to support an effective operation of the constitutional review process without altering the underlying requirements of the primacy of Union law. ${ }^{59}$ That would symbolically and practically elevate the role of the Charter without, crucially, reasserting an exclusive capacity of the constitutional court to find a violation of the Charter. Other domestic courts would retain the capacity to disapply national statues violating the Charter on a case-by-case basis, while the Constitutional Court could go further with an annulment erga omnes.

\section{Karlsruhe and the European Union: a tale of two courts}

Both the outcome and the reasoning of the First Senate's Right to be Forgotten decisions are defined by an inbuilt openness towards EU law, which contrasts markedly with the critical and occasionally hostile attitude that permeates the judgments of the Second Senate, which is the author of most ultra vires

\footnotetext{
${ }^{55}$ On the distinction, see the Spanish Tribunal Constitucional 13 December 2004, Declaration 1/2004, Tratado de Lisboa; and BVerfG 30 June 2009, 2 BvE 2/08 et al., Vertrag von Lissabon, paras. 331-335; as well as M. Avbelj, 'Supremacy or Primacy of EU Law', 17 ELJ (2011) p. 744 at p. 746-760.

${ }^{56}$ Cf Art. 100(1) Grundgesetz; Sections 78, 82(1), 95(3) in conjunction with Section 31 Bundesverfassungsgerichtsgesetz (Law on the Federal Constitutional Court); and K.F. Gärditz, 'Grundrechts-Mobile statt starrer Kompetenzschichten', Verfassungsblog, 19 January 2020, 〈verfassungsblog.de/grundrechts-mobile-statt-starrer-kompetenzschichten $\rangle$, accessed 18 June 2020.

${ }^{57}$ Both cases concerned the application of abstract statutory rules by lower courts and did not, therefore, involve a potential invalidity of the statute.

${ }^{58}$ See the contributions of 'Stiller Leser' (acronym) and the author to the comment section of 'Im „Kreuzfeuer“ des Zweiten Senats', Verfassungsblog, 13 April 2020, 〈verfassungsblog.de/im-kreuzfeuer-des-zweiten-senats/\#comments $\rangle$, accessed 18 June 2020.

${ }^{59} \mathrm{BVerfG}$, supra n. 31 , para. 67 can be read to hint at this outcome.
} 
and constitutional identity judgments that do not directly concern fundamental rights. ${ }^{60}$ That cleavage is no novelty but deserves our attention nonetheless, since it highlights that the broader effects of the new decisions need not be as proEuropean as some international observers might intuitively have assumed. More specifically, the novel standpoint on fundamental rights overturned the original Solange rulings, but did not affect the alternative constitutional caveats under the ultra vires and constitutional identity review, which the First Senate reaffirmed explicitly. ${ }^{61}$ Several recent judgments of the Second Senate confirm that these standards are alive and kicking: the stern PSPP judgment delivered five months later demonstrated that the Constitutional Court presents itself as a Janus-faced institution when it comes to the approach towards the supranational legal order. ${ }^{62}$

The next section will discuss the extent to which the Right to be Forgotten decisions embody a forward-looking style of constructive influence on European affairs that deviates from the antagonistic and occasionally hostile attitude of the ultra vires and constitutional identity review. The First Senate seems to have made a deliberate choice to change course on the domestic status of the Charter without involving the Second Senate. It expended considerable energy to demonstrate that the new line did not explicitly diverge from previous judgments of the Second Senate, which would have required a decision of the Plenary. ${ }^{63}$ That outcome may possibly be defended on purely formal grounds, but it certainly contradicts conceptual foundations of the previous case law. ${ }^{64}$ It is, therefore, an expression of unfriendly behaviour within the Court, which had seen similar tensions previously. ${ }^{65}$ I expect the Second Senate to grudgingly subscribe to the Right to be Forgotten decisions at the end of the day instead of referring potential follow up cases to the Plenary with little chance of success. ${ }^{66}$ Doing so would not,

\footnotetext{
${ }^{60}$ Generally speaking, the First Senate deals with human rights, while the Second Senate decides other questions under Section 14 Bundesverfassungsgerichtsgesetz.

${ }^{61}$ See BVerfG, supra n. 31, para. 49.

${ }^{62}$ See BVerfG, supra n. 43; domestic constitutional requirements for involvement in EU affairs were considerably tightened on the occasion of a verdict on the Patents Court by BVerfG 13 February 2020, supra n. 42; Banking Union was given a critical go-ahead with strings attached by BVerfG 30 July 2019, 2 BvR 1685/14 et al.

${ }^{63}$ See BVerfG, supra n. 31, paras. 85-93; and Section 16 Bundesverfassungsgerichtsgesetz.

${ }^{64}$ Reference to the Plenary is only mandatory when a position had been explicitly confirmed in the core argument of a decision of a Senate with the involvement of all judges; see Kämmerer and Kotzur, supra n. 44, p. 183-184; and Wendel, supra n. 38, p. 167.

${ }^{65}$ The First Senate deviated from the position of the Second Senate on restrictions on the use of the Islamic headscarf; see C. Möllers, 'Der Kopftuch-Beschluss: Zwei Senate, zwei Gerichte?', Verfassungsblog, 14 March 2015, 〈verfassungsblog.de/a-tale-of-two-courts〉, accessed 19 June 2020.

${ }^{66}$ Note that BVerfG, supra n. 31, para. 142 informed us about a unanimous decision by the First Senate, which could be expected to be joined by at least one member of the Second Senate, possibly
} 
however, put into question the ultra vires and constitutional identity control the Second Senate reasserted so forcefully in PSPP.

\section{No PARADOX: INFLUENCE THROUGH 'SUBORDINATION'}

The experience of federal states demonstrates that human rights can have a crucial impact on the vertical balance of power. ${ }^{67}$ Indeed, the German example provides ample evidence that federal courts may activate human rights with centripetal effects. Human rights in the constitutions of Germany's regions, the Länder, never gained much prominence; nor did their constitutional courts. ${ }^{68}$ This background helps us to understand that the Right to be Forgotten decisions should not be misconstrued as a willing abdication by the Court in Karlsruhe. On the contrary, the Court can be expected to project the weight of decades of elaborate human rights case law to a European level in coming years, thereby effectively turning the previous reliance on the threat of the 'last word' of the German Constitution into a forward-looking power of the 'first word'.

\section{Preliminary references: a new normality}

German courts are generally loyal partners of the Court of Justice; they refer more questions to Luxembourg than courts from other member states in similar circumstances. ${ }^{69}$ Similarly, the Bundesverfassungsgericht has played an active role for years by ensuring, on the basis of constitutional complaints by individuals challenging the absence of a reference, that domestic courts respect their obligations under Article 267 TFEU. In line with the separation thesis, described above, it refrained, however, from consulting the Court of Justice in human rights cases. Both Right to be Forgotten decisions state unambiguously that this will change in the future. The prevalent 'fusion' of domestic and supranational human rights entails that 'references will have to be considered to a much greater extent' ${ }^{70}$ We will have to see whether the Constitutional Court will take that commitment

by D. König or C. Langenfeld, who had recently objected to the overly strict line of the Second Senate on EU affairs; see supra n. 42.

${ }^{67} \mathrm{See}$ C. Fercot, 'Perspectives on Federalism. A Comparative Analysis of German, American and Swiss Law', 4 EuConst (2008) p. 302.

${ }^{68}$ See K. Gärditz, 'Grundrechte im Rahmen der Kompetenzordnung', in J. Isensee and P. Kirchhof (eds.), Handbuch des Staatsrechts, Vol. IX, 3rd edn (C.F. Müller 2011) \$189 paras. 38-49; as well as Fercot, supra n. 67, p. 319.

${ }^{69}$ See M. Broberg and N. Fenger, 'Variations in Member States' Preliminary References to the Court of Justice', 19 ELJ (2013) p. 488.

${ }^{70} \mathrm{BVerfG}$, supra n. 31, para. 70 for situations of full harmonisation; for other scenarios with a lesser degree of commitment, see BVerfG, supra n. 34, para. 72. 
seriously. While the author expects regular references henceforth, at least in scenarios of full harmonisation, the first seven months after the Right to be Forgotten rulings did not result in a single preliminary reference.

Judges may have unconvincingly refrained from a reference in the case at hand in line with the comments below, but recognised the Court of Justice as the 'ultimate interpreter' of Union law and presented us with a realistic assessment of the CILFIT criteria about when judges may refrain from referring questions to the Court in Luxembourg. ${ }^{71}$ In doing so, they persuasively rejected an idea that had been put forward by the Austrian Constitutional Court. In contrast to what judges in Vienna had earlier proclaimed, the court in Karlsruhe does not consider a widespread agreement among domestic courts (and in academic writing) as an indication of an acte claire not requiring a reference. ${ }^{72}$ That is an important caveat, which is particularly relevant in a country like Germany with a lively domestic discourse on EU law, which is often disconnected from the transnational debate. ${ }^{73}$ To state that discrepancies in or implications for the pan-European conception of human rights are an indicator for a mandatory reference coincides with recent case law of the European Court of Justice. ${ }^{74}$ Purists may object that any case involving the Charter even marginally should be sent to Luxembourg, but on a practical level that is unfeasible and does not coincide with the established practice of domestic courts across Europe. ${ }^{75}$ It should not be read as sign of opposition, therefore, if the Bundesverfassungsgericht reflects on the criteria guiding the application of the CILFIT test.

Neither should it be seen as a principled act of resistance to declare that established case law of the European Court of Human Rights may amount to an acte claire for identical rights under the Charter. ${ }^{76}$ To be sure, the Courts in Luxembourg and Strasbourg have occasionally disagreed, for instance on mutual trust, but such discrepancies are an exception to the rule of a generally homogenous parallel evolution of the European Convention and the Charter. ${ }^{77}$ The

${ }^{71}$ See BVerfG, supra n. 31, paras. 69-70.

${ }^{72} \mathrm{Cf}$ BVerfG, supra n. 31, para. 71 without a reference to the position of the Verfassungsgerichtshof, supra n. 49, para. 44; see also Merli, supra n. 50, p. 358.

${ }^{73}$ See D. Thym, The Limits of Transnational Scholarship on EU Law (EUI Working Paper LAW 2016/14) p. 2-16.

${ }^{74}$ See ECJ 9 September 2015, Case C-160/14, Ferreira da Silva e Brito et al., paras. $41-44$ notwithstanding ECJ 4 October 2018, Case C-416/17, Commission v France, paras. 105-109 in a scenario in which the legal situation under EU law was very unclear.

${ }^{75}$ See M. Broberg and N. Fenger, 'Finding Light in the Darkness', 30 YEL (2011) p. 180; A. Turmo, 'A Dialogue of Unequals', 15 EuConst (2019) p. 340 at p. 353-356; and Masing, supra n. 30, p. 505-506.

${ }^{76}$ See BVerfG, supra n. 31, para. 70.

${ }^{77}$ Previous discrepancies have given way to a convergence of principle, even though K. Lenaerts, 'La vie après l'avis', 54 CML Rev (2017) p. 805 at p. 831-834 presented an overly rosy picture when he refuted earlier disagreement. 
position of the Bundesverfassungsgericht might have been influenced by its experience of a recent Grand Chamber judgment on the human rights requirements for prison cells, which highlighted the lead function of judgments of the European Court of Human Rights, and which was based on a German reference the Constitutional Court had mandated. ${ }^{78}$ That might be a model for the future. By reminding the European Court of Justice of the case law of the Strasbourg Court, constitutional courts further the convergence of the pan-European human rights framework, thus effectively diminishing the capacity of the Court of Justice to establish itself as primus inter pares. ${ }^{79}$ The Bundesverfassungsgericht will insist on a network-based evolution of general principles, ${ }^{80}$ even if it accepts that the position of the Court in Luxembourg takes precedence in individual cases.

In one respect, judges in Karlsruhe hesitated. They explicitly left undecided whether they will assume jurisdiction when the validity of Union law is at stake either directly because a constitutional complaint maintains that secondary law violates the Charter or indirectly when they are called upon to annul domestic rules implementing mandatory supranational prescriptions. ${ }^{81}$ In such scenarios, the Court of Justice will usually adopt a uniform standpoint without leaving discretion to national courts - and has made it crystal clear that they must consult Luxembourg, even if domestic implementing legislation is at stake. ${ }^{82}$ Apparently, the Bundesverfassungsgericht does not want to act as a 'servant' preparing the European Court of Justice verdict and might leave that function to other courts. It seems to me that such an outcome would misapprehend the role of references.

\section{Practice: a pain in the neck of the European Court of Justice?}

In recent years the Bundesverfassungsgericht has learned its lesson. Having declined jurisdiction in cases involving the Charter, it effectively left the initiative for framing the answer to other actors. The European Court of Justice's activism in the field of data protection, mentioned above, was a case in point, effectively dethroning the Court in Karlsruhe as a champion of high protection standards. It may be a sign of stubbornness that the judges decided Right to be Forgotten II on their own accord by maintaining unconvincingly that the generic balance between

\footnotetext{
${ }^{78}$ ECJ 15 October 2019, Case C-128/18, Dorobantu, paras. 70-79 originated in BVerfG 19 December 2017, 2 BvR 424/17 and was decided two weeks before Right to be Forgotten.

${ }^{79}$ See the President of the Second Senate A. Voßkuhle, 'Pyramid or Mobile?', 34 Human Rights Law Journal (2014) p. 1-3; and A. Voßkuhle, 'Multilevel Cooperation of the European Constitutional Courts', 6 EuConst (2010) p. 175.

${ }^{80}$ Note that BVerfG, supra n. 31, para. 139 justified a distinction from earlier ECJ judgments on the right to be forgotten amongst others by referring to an ECtHR ruling.

${ }^{81}$ See BVerfG, supra n. 31, para. 51.

${ }^{82}$ See ECJ 22 June 2010, Case C-188/10 \& C-189/10, Melki \& Abdeli, paras. 54-56; ECJ 11 September 2014, Case C-112/13, A, paras. 39-44; and Bobek, supra n. 54, p. 297-298.
} 
data protection and the freedom of expression - on which they insisted - coincided with previous judgments of the Court in Luxembourg, which had emphasised the primacy of data protection in regular circumstances. ${ }^{83}$ Arguably, it would have been an act of symbolic submission if the First Senate had combined the fundamental reversal of earlier case law with a reference to Luxembourg.

At the same time, the balance between data protection and the freedom of expression, on which the Constitutional Court insisted, is a fine example of why it might wish to engage in proactive references in the future. It must be remembered that the Right to be Forgotten I case had been pending in Karlsruhe since 2013. If judges had referred the matter shortly after the Google Spain judgment, which had first declared a primacy of data protection, it might have been much easier to push the Court of Justice in a certain direction before the case law consolidated itself. The example of the Taricco saga shows that the judges in Luxembourg are willing to listen to domestic constitutional courts. If the German Constitutional Court aims at shaping the course of events, it is well advised to communicate with the European Court of Justice early on: such references can be more than polite questions; they can present an elaborate solution to the Court of Justice on a silver platter, which it can hardly refuse.

\section{The power of the 'first word'}

References are, in other words, not to be misconstrued as acts of submission, even if the Bundesverfassungsgericht recognises the Court of Justice as the 'ultimate interpreter' of the Charter, who has the final word. The example of the data protection case law demonstrates why the 'first word' can be more effective in terms of determining the direction of pan-European human rights case law. By sending proposals to Luxembourg, judges in Karlsruhe could effectively export core elements of the German fundamental rights tradition to the European level. To be sure, they will never be able to dictate a specific outcome, and their input will coalesce with other traditions, but they have a realistic chance of projecting the wealth of experience and doctrinal opulence of German human rights case law to the European level by means of constructive and articulate references. ${ }^{84}$ In that respect, the Right to be Forgotten rulings arguably epitomise a change

\footnotetext{
${ }^{83}$ BVerfG, supra n. 31, paras. 121, 137-141 contrasts markedly with ECJ 24 September 2019, Case C-136/17, GC et al., paras. 66-68; see P. Friedl, 'New Laws of Forgetting', Europeanlawblog, 12 December 2019, (europeanlawblog.eu/2019/12/12〉, accessed 3 June 2020; to depart from earlier ECJ judgment without a reference will usually violate Art. 267(3) TFEU; see ECJ, C-416/17, supra n. 74, para. 11; and Turmo, supra n. 75, p. 352.

${ }^{84}$ Similarly N. Lupo, 'The Advantage of Having the "First Word" in the Composite European Constitution', 10 Italian Journal of Public Law (2018) p. 186 at p. 187-188; and O. Pollicino, 'Common Constitutional Traditions in the Age of the European Bill(s) of Rights', in L. Violini
} 
of strategy from the defensive threat of the 'last word' 85 under the ultra vires and constitutional identity control standards towards proactive influence by means of persuasive recommendations on how to interpret the Charter. While it could be argued that the 'first word' has more sway when it is buttressed by the threat of disobedience, our analysis transcends conflict-based descriptions by emphasising the procedural and contextual benefits of the 'first word' in terms of framing the debate as a powerful tool in its own right.

It should be noted that the working method of the Court of Justice can support the weight of preliminary references, since it often establishes a coherent set of principles step by step in a series of rulings over time instead of laying down a grand quasi-legislative solution in a single judgment, as the Bundesverfassungsgericht often does. ${ }^{86}$ Experience with the Charter over the past decade shows, moreover, that the Court of Justice takes the position of domestic courts much more seriously than in its previous case law on the general principles of Community law, which were often grounded on a shallow inspection of the domestic legal practice. ${ }^{87}$ Beyond the specificities of the judicial reasoning, discourse theory and experimental psychology illustrate that conceptual 'framing', here via preliminary references, can have a palpable impact on the course and the outcome of debates. ${ }^{88}$

Such a trend towards greater cooperation between constitutional courts and the Court of Justice arguably transcends an idealistic process of communicative action in which diverse actors explore the best outcome; it can be combined with a realistic assessment of the relative weight of different judicial institutions realising that their success or failure depends on mutual cooperation, ${ }^{89}$ which occasional disagreement and even conflict need not contradict. ${ }^{90}$ After all, the Court of

and A. Baraggia (eds.), The Fragmented Landscape of Fundamental Rights Protection in Europe (Elgar 2018) p. 42 at p. 63-68.

${ }^{85}$ The formulation is used by the Second Senate, e.g. in BVerfG, supra n. 55, para. 340; on the underlying defensive attitude in contrast to the earlier Solange rulings, see Thym, supra n. 41, p. 1809.

${ }^{86}$ See D. Sarmiento, 'Half a Case at a Time', in van de Heyning and de Visser, supra n. 54, p. 14-22; K. Lenaerts, 'The Court's Outer and Inner Selves', in M. Adams et al. (eds.), Judging Europe's Judges (Hart Publishing 2013) p. 13 at p. 17-39; and M.P. Maduro, 'Contrapunctual Law', in N. Walker (ed.), Sovereignty in Transition (Hart Publishing 2003) p. 501 at p. 511-517.

${ }^{87}$ See F.C. Mayer, 'Constitutional Comparativism in Action', 11 ICON (2013) p. 1003 at p. $1005-1010$.

${ }^{88}$ See A. Tversky and D. Kahnemann, 'The Framing of Decisions and the Psychology of Choice', 30 Science (1981) p. 453.

${ }^{89}$ See Bobek, supra n. 54, p. 305-313; O. Frishman, 'Transnational Judicial Dialogue as an Organisational Field', 19 ELJ (2013) p. 739-758; and A. Torres Pérez, Conflicts of Rights in the European Union (Oxford University Press 2009) ch. 5.

${ }^{90} C f$ P.M. Huber, 'Auslegung und Anwendung der Charta der Grundrechte', Neue Juristische Wochenschrift (2011) p. 2385-2390. 
Justice understands that the normative force of Union law requires the loyal cooperation of the domestic judiciary, ${ }^{91}$ which can be fostered by a constructive working relationship with the highest courts, which appears to have advanced in recent years ${ }^{92}$ - notwithstanding the serious setback which the Second Senate's PSPP judgment presents. Experience shows that domestic courts may stop referring cases on specific themes to the judges in Luxembourg if the latter respond to intricate questions with simplistic answers that give domestic courts little guidance. ${ }^{93}$ Indeed, balance between uniformity and flexibility in the domestic application of the Charter will be a decisive factor defining the future relationship between the Bundesverfassungsgericht and the Court of Justice.

\section{Human rights' introspection in Disguise? Parallel application of THE GRUNDGESETZ}

Some initial commentators had criticised the Right to be Forgotten I ruling as a sort of poisoned chalice concealing the continued institutional self-interest of the Bundesverfassungsgericht and the claim to constitutional autonomy behind the surface of a seemingly pro-European judgment. ${ }^{94}$ It seems to me that this view perpetuates the zero-sum rationale under the 'separation thesis', according to which one party gained what the other lost. That is not to say, crucially, that the age of 'fusion' will be a brave new world of inter-court and normative harmony. Disagreement, debates and occasional conflict will persist when different actors struggle to define the optimal outcome. These disputes will not primarily concern the resolution of individual cases, in relation to which the German Constitutional Court recognised the lead function of the Court of Justice. When it comes to generalised criteria on how to interpret human rights, however, we can expect a vibrant and occasionally antagonistic overall setting.

\section{'Primary' application of the Grundgesetz as pragmatic guidance}

It was explained at the beginning of this paper that the Bundesverfassungsgericht distinguished areas of full harmonisation from areas of member state discretion. While the former will henceforth be assessed in light of the Charter, the latter

${ }^{91}$ See H. Sauer, Jurisdiktionskonflikte in Mehrebenensystemen (Springer 2008) ch. 8.

${ }^{92}$ See the empirical study by T. Pavone and D.R. Kelemen, 'The Evolving Judicial Politics of European Integration', 25 ELJ (2019) p. 352 at p. 356-358.

${ }^{93}$ See Sarmiento, supra n. 86, p. 29-35; and Takis Tridimas, 'Constitutional Review of Member State Action', 9 ICON (2011) p. 737 at p. 755.

${ }^{94}$ See Kämmerer and Kotzur, supra n. 44, p. 181-183 and passim; and D. Burchardt, 'Backlash against the Court of Justice of the EU?', 21 GLJ (2020) Special Issue S1, p. 1 at p. 13-17. 
continue to be defined by a parallel application of the Charter and the Grundgesetz in line with the Right to be Forgotten I decision, which ambiguously put forward a novel 'presumption' that the German Constitution generally guarantees the same level of protection as the Charter and should be applied 'primarily' by domestic courts. ${ }^{95}$ The implications of this move remain unclear, although the Court's reasoning and contextual factors indicate that the 'primary' application of the Grundgesetz does not aim at a jingoistic human rights' introspection in disguise.

The sheer length of the Right to be Forgotten decisions indicates that the First Senate carefully pondered the doctrinal, theoretical and practical repercussions of the rulings both in terms of substantive law and court procedure. After all, the Bundesverfassungsgericht alone decides almost 6,000 cases per year, while the German judiciary as a whole deals with more than three million cases. Their effective functioning requires consistent fundamental rights standards, which the established principles guiding the application of the Grundgesetz can provide. ${ }^{96}$ I suggest, therefore, that the presumption of equivalence should be read, above all, as a pragmatic tool to sustain the effective operation of the judiciary on the basis of the doctrinal characteristics of fundamental rights in the Grundgesetz. ${ }^{97}$ I conceive, in other words, the semantically ambiguous 'primary' (primäre) application of the Grundgesetz as an essentially temporal guideline, not as normative primacy. ${ }^{98}$

Judges were crystal-clear that the presumption of equivalence can be rebutted, especially when the wording and the context of secondary legislation or the European Court of Justice case law indicate a different level of protection under the Charter. In such a scenario, domestic courts and the Bundesverfassungsgericht have to embark on a detailed inspection, including the possibility of a reference to the Court of Justice. ${ }^{99}$ My experience of judicial practice in field of migration suggests that this guidance is pragmatic. In the field of migration, EU legislation and the Charter remained background norms, which were cited at best, until judgments from Luxembourg served as a catalyst for a wider interest in secondary law and the Charter, which gradually took centre stage in questions such as the transfer of asylum seekers. A similar process of discovery can be expected in other

\footnotetext{
${ }^{95}$ See BVerfG, supra n. 34, paras. 48, 55-72 and the first headnote of the decision.

${ }^{96}$ Their stability is supported by contextual factors, which cannot be changed overnight, such as university education and the notorious state exams, legal literature including the ubiquitous commentaries, and the inventory of decades of case law incorporating the Grundgesetz into different segments of the legal order; see Thym, supra n. 73, p. 14-16, 19-22.

${ }^{97}$ Similarly Wendel, supra n. 38, p. 161.

${ }^{98}$ Contrary to Burchardt, supra n. 94, p. 14-15 referring to the vaguely formulated para. 63.

${ }^{99}$ See BVerfG, supra n. 34, paras. 67-73.
} 
areas. Over the years, the Charter will shape ever more legal question in diverse areas, thereby gradually supplanting the 'primary' application of the Grundgesetz.

What is more, the Bundesverfassungsgericht emphasises that the Charter will influence the interpretation of the German Constitution - something the First Senate had done before, for instance when it enhanced the protection of same-sex couples, extended fundamental rights to legal persons from other member states, and reinforced protection against return or extradition. ${ }^{100}$ Again, such realignment of human rights standards will be a cumbersome process, complicated by the idiosyncratic doctrinal rigidity of fundamental rights in the German legal tradition, which cannot easily integrate distinct impulses from the EU legal order. ${ }^{101}$ The Right to be Forgotten decisions are a good example, since the Bundesverfassungsgericht reasserts the German tradition of indirect horizontal effect in the domain of implementing discretion, ${ }^{102}$ while applying the European Court of Justice's concept of direct horizontal effect in the domain of full harmonisation (which international observers often wrongly mistake as a supranational replica of the German tradition). ${ }^{103}$ Along similar lines, judges will have to explore the potential for overlap, harmonisation and continued doctrinal distinction across diverse segments of the legal order.

\section{Ordinary courts as an institutional counterbalance}

It is well-known that the empowerment of domestic courts has been central to the success of the law-based integration project. ${ }^{104} \mathrm{~A}$ side-effect of this transformation has been the reconfiguration of judicial authority in member states, with constitutional courts losing previous privileges in terms of centralised judicial review, when ordinary courts can bypass internal hierarchies by consulting the European Court of Justice, and disapplying domestic rules in light of EU law. ${ }^{105}$ Against this background, it does not come as a surprise that constitutional

${ }^{100}$ See C.D. Classen, 'Zuviel des Guten?', Juristenzeitung (2019) p. 1057 at p. 1058-1061; BVerfG 19 July 2011, supra n. 47, paras. 75-81; and the Second Senate in BVerfG 30 October 2019, 2 BvR 828/19, paras. 42-44, 52 .

${ }^{101}$ See Thym, supra n. 35, p. 61-62; and F. Michl, 'Zur selektiven Rezeption europäischer Rechtsprechung', Europarecht (2018) p. 456.

${ }^{102}$ See BVerfG, supra n. 34, paras. 76 ff, while ensuring that the outcome does not contradict the ECJ's standpoint.

${ }^{103}$ See BVerfG, supra n. 31, paras. 97, $137 \mathrm{ff}$.

${ }^{104}$ See the classic accounts by J.H.H. Weiler, 'The Transformation of Europe', 100 Yale Law Journal (1990/91) p. 2403 at p. 2413-2423; and K.J. Alter, 'The European Court's Political Power', 19 Western European Politics (1996) p. 458 at p. 466-471.

${ }^{105}$ See Bobek, supra n. 54, p. 290-300. 
courts try to reassert their institutional weight at a time when the Charter signals an expansion of the supranational legal order to core areas of constitutional adjudication. ${ }^{106}$ Both the Italian and the Austrian Constitutional Courts made moves in that direction, even though they finally had to acknowledge that domestic courts retain the option to communicate directly with judges in Luxembourg. ${ }^{107}$

Right to be Forgotten II can be read as an attempt to reassert the pivotal institutional role of the Bundesverfassungsgericht when judges considered, without giving a definite answer, whether the application of the Charter by the Constitutional Court implies that only the latter should be considered the highest court for the purposes of Article 267(3) TFEU. ${ }^{108}$ I doubt whether the judges will answer that question in the affirmative. First, the ruling explicitly acknowledged that such a conclusion would only concern the human rights dimension of a case, since the federal courts retain the ultimate domestic authority over the interpretation of statutory rules. ${ }^{109}$ In practical terms, it could be difficult - if not impossible - to neatly distinguish between the human rights and the legislative dimension of a case, since both are often inextricably intertwined in the judicial reasoning of the Court of Justice. ${ }^{110}$ Second, ordinary courts would retain the ability to consult judges in Luxembourg on the basis of Article 267(2) TFEU even if the Constitutional Court considered itself to be the last domestic instance on interpretation of the Charter. Other domestic courts cannot be expected, however, to give way to an institutional predominance of constitutional judges willingly; over the years, they have become accustomed to communicating directly with the European Court of Justice, thereby transforming important areas of domestic law, such as migration or non-discrimination, which would have been a prerogative of the Constitutional Court three decades ago. ${ }^{111}$ Even if the Court in Karlsruhe reasserted itself as the highest court when it comes to human rights, other courts would continue sending references under Article 267(2) TFEU. In doing so, they would effectively serve as an institutional counterbalance to the Constitutional Court.

\footnotetext{
${ }^{106}$ Remember that the switch from 'separation' to 'fusion', described in the first section, was supported by the desire of constitutional courts to prevent a further loss of authority.

${ }^{107}$ See Martinico and Repetto, supra n. 23, p. 737-745; Pöschl, supra n. 50, p. 585-586; and D. Gallo, 'Challenging EU Constitutional Law', 25 ELJ (2019) p. 434 at p. 448-452.

${ }^{108}$ See BVerfG, supra n. 31, paras. 72-76.

${ }^{109}$ I.e. they remain the highest court for the purposes of Art. 267(3) TFEU insofar as the interpretation of secondary legislation is concerned.

${ }^{110}$ There is, to my knowledge, little literature on the overlap of statutory and human rights arguments - a synthesis that is reinforced by the double function of the ECJ as a supreme and constitutional court whose jurisdiction is not confined to human rights.

${ }^{111}$ See D. Thym, Migrationsverwaltungsrecht (Mohr Siebeck 2010) at p. 246-249; and A. Stone Sweet and K. Stranz, 'Rights Adjudication and Constitutional Pluralism in Germany and Europe', 19 Journal of European Public Policy (2012) p. 92 at p. 97-104.
} 


\section{Leeway under EU law and human rights' interconnectivity}

Long and complex judgments often contain different levels of analysis. Thus, the practice-oriented presumption of equivalence, which underlies the 'primary' application of the Grundgesetz, coincides with a principled insistence on the axiomatic 'unity in diversity' of the pan-European human rights framework. Right to be Forgotten I, on the parallel application of national constitutions and the Charter in areas of incomplete harmonisation, accentuated this attitude. It highlighted safeguards in primary law which protect a certain leeway of the member states and emphasised the recent practice of the Court of Justice, including symbolic cases such as Melloni or Omega as well as the everyday practice in domains in which secondary legislation is loosely knit. ${ }^{112}$ In such areas, the Court will usually refrain from in-depth interventions on human rights grounds and insist on standards which are 'coarsely meshed (grobmaschig) to ensure that state action does not appear "unreasonable". ${ }^{113}$ Such quotes are emblematic of a decision that epitomises a profound knowledge of EU law and practice.

While the observations above present themselves as a realistic depiction of the status quo under the 'fusion thesis', with the Court of Justice recognising the relative autonomy of member states, other segments of the ruling adopted a more demanding tone. The First Senate emphasised the need for country-specific solutions in areas that reflect specific historic experiences or contemporary social and political struggles, echoing the - much harsher - constitutional identity caveat of the Second Senate, which it did not cite in this context. ${ }^{114}$ The First Senate referred to several previous judgments in which it had distinguished the legal situation in Germany from decisions delivered by the European Court of Human Rights regarding other countries, thereby effectively modifying the effects of the international case law within the German legal order. ${ }^{115}$ In the EU context, such a move will usually require a preliminary reference, which the Bundesverfassungsgericht evaded in Right to be Forgotten II when it instructed domestic courts to integrate the freedom of expression into the balancing exercise. ${ }^{116}$

${ }^{112}$ See BVerfG, supra n. 34, paras. 48-54; for broader overviews see J. Zglinski, 'The Rise of Deference', 55 CML Rev (2018) p. 1341; and M. Dawson, The Governance of EU Fundamental Rights (Cambridge University Press 2017) ch. 3.

${ }^{113}$ BVerfG, supra n. 34, paras. 52 referring to ECJ 16 October 2007, Case C-411/05, Palacios de la Villa, para. 68 ff.; and ECJ 12 October 2010, Case C-45/09, Rosenbladt, paras. 41, 51, 69.

${ }^{114}$ See BVerfG, supra n. 34, paras. 62, 66; and the theoretic argument by J. Komárek, 'National Constitutional Courts in the European Constitutional Democracy', 12 ICON (2014) p. 525; and J. Gerards, 'Pluralism, Deference and the Margin of Appreciation Doctrine', 17 ELJ (2011) p. 80.

${ }^{115}$ See, most recently, BVerfG 2018, 2 BvR 1738/12 et al.; and M. Jacobs and M. Payandeh, 'The Ban on Strike Action by Career Civil Servants under the German Basic Law', 21 GLJ (2019) p. 223 at p. 230-234.

${ }^{116}$ See supra n. 83 and accompanying text. 
At an intermediate level of abstraction, the comments hint at an underlying challenge. It is true that the Court of Justice generally distinguishes between the 'interpretation' of EU law, for which it assumes the ultimate (i.e. not sole) responsibility, ${ }^{117}$ while domestic courts are meant to 'apply' these principles. ${ }^{118}$ In practice, however, the distinction will be difficult to uphold. The sheer complexity of today's human rights case law implies that judges in Luxembourg will have neither the capacity nor the institutional authority to establish overarching principles guiding the application of the Charter in literally tens of thousands of cases in diverse areas of secondary legislation single-handedly. They depend on the input and the continued support of the highest courts in the member states to uphold, to consolidate and to fine-tune the general principles defining the day-to-day application of the Charter on the ground. In that respect, reliance on established case law of the European Court of Human Rights and preliminary references will be essential, even though they will not entirely rationalise all situations, especially considering that European Court of Justice case law occasionally lacks systemic coherence. ${ }^{119}$ The overarching network of pan-European human rights protection is bound to embrace elements of divergence and potential friction, which we should learn to live with.

\section{Conclusion}

Sometimes it can be a disadvantage to have a long relationship. Patterns developed early on can endure over decades irrespective of changes in the environment. A telling example is the case law of the German Constitutional Court on fundamental rights, which had supported the demarcation of domestic and supranational human rights ever since the famous Solange rulings. In the Right to be Forgotten decisions, the Bundesverfassungsgericht made an about-turn and followed other constitutional courts in embracing the Charter of Fundamental Rights as a standard of judicial review. It indicated that preliminary references to the Court of Justice will become a new routine, which should not be misconstrued as an act of subordination. Judges in Karlsruhe presented their Court as a self-conscious actor, which will request the evolution of a coherent set of supranational

\footnotetext{
${ }^{117}$ Kämmerer and Kotzur, supra n. 44, p. 181 misconceive the ECJ's lead function when they designate it as an 'exclusive interpretative authority'; much more nuanced is Wendel, supra n. 38, p. 162, who is critical of an interpretation transcending an application by the BVerfG nevertheless.

${ }^{118}$ See BVerfG, supra n. 31, para. 65 and the ECJ case law cited therein.

${ }^{119}$ See the holistic analysis of case law on free movement and migration law by D. Thym, 'The Elusive Limits of Solidarity', 52 CML Rev (2015) p. 17 at p. 27-39, 45-47; and D. Thym, 'A Bird's Eye View on ECJ Judgments on Immigration, Asylum and Border Control Cases', 21 EJML (2019) p. 166 at p. $179-192$.
} 
fundamental rights standards and will project the wealth of experience and doctrinal opulence of German human rights case law to the European level. The 'first word' of future preliminary references from Karlsruhe might prove more powerful than the latent threat of the 'last word', which the ultra vires and constitutional identity caveats continue to epitomise.

Substantive and procedural patterns of German constitutional law elucidate twists in the case law, when the transfer of sovereign rights implies that the fundamental change of direction is not adequately reflected in the wording of the Grundgesetz. Idiosyncrasies of the constitutional review procedure might even result in a domestic upgrade of the primacy of the Charter towards supreme legal effects. Even if considerations of realist institutional self-interest help explain the Right to be Forgotten decisions, the broader effects can result in a welcome strengthening of the pan-European human rights framework at a time when the rule of law is under attack in several member states. While the new approach reinforces the constitutional rank of the Charter, it will not simply buttress the position of the Court of Justice. A powerful and self-conscious actor like the Bundesverfassungsgericht will insist on adequate checks and balances, including a relative autonomy of the domestic judiciary within the realms of the Charter. 